\title{
Prevalence of Metabolic Syndrome Among Rural Women in a Village, Iran
}

\author{
Maryam Baradaran-Binazir* and Fariba Heidari \\ Social Determinants of Health Research Center, Tabriz University of Medical Sciences, Iran
}

Submission: April 11, 2021; Published: May 11, 2021

* Corresponding author: Maryam Baradaran-Binazir, Faculty of Medicine, Social Determinants of Health Research Center, Health Management and Safety Promotion Research Institute, Tabriz University of Medical Sciences, Golgasht Ave. Tabriz, Iran

\begin{abstract}
The prevalence of metabolic syndrome (MS) differs among populations. The aim of this study was to identify the prevalence of MS and its risk factors among rural women in the Saeidabad village, East Azarbaijan on province, Iran. This cross-sectional study was done on the rural women aged 30-49 years in the primary health care of Saeidabad village, 2019. The National Cholesterol Education Program Adult Treatment Panel III was applied to identify MS. Totally 258 rural women participated in our study. Prevalence of metabolic syndrome was $41.8 \%$ among rural women. So, our study demonstrated that the prevalence of MS was high among rural women and increased with increasing age. The most prevalent factor of MS was high waist circumference.
\end{abstract}

Keywords: Women's park; Physical health; Social interaction; Women's sports

Abbreviations: MS: Metabolic Syndrome; HDL: High-Density Lipoprotein; ATP: Adult Treatment Panel; BP: Blood Pressure

\section{Introduction}

The metabolic syndrome (MS) is a group of associated MS risk factors that are identified by abdominal obesity, high blood pressure, high fasting blood glucose level, raised triglycerides, and decreased high-density lipoprotein (HDL) cholesterol [1]. There are different descriptions for the identifying of MS now [2]. The National Cholesterol Education Program Adult Treatment Panel (ATP) III describes MS as having three or more of the coming criteria: an HDL of $<40 \mathrm{mg} / \mathrm{dl}$ in men and $<50 \mathrm{mg} / \mathrm{dl}$ in women, a systolic/diastolic blood pressure (BP) of $\geq 130 / 85 \mathrm{~mm} \mathrm{Hg}$, a triglyceride level at least $150 \mathrm{mg} / \mathrm{dl}$, an FBG level of $\geq 100 \mathrm{mg} /$ $\mathrm{dl}$, and a waist circumference $(\mathrm{WC})>102 \mathrm{~cm}$ in men and $>88 \mathrm{~cm}$ in women [3]. The prevalence of MS is elevated throughout the world. In the United States, prevalence of MS was 34\% among young adults [4]. A report of the results of other studies done on healthy people from some of European countries demonstrated that the prevalence of MS was $15.7 \%$ in men and $14.2 \%$ in women [5]. The prevalence of MS was between $10 \%$ and $20 \%$ in the Asia [6]. There are some investigations demonstrated the prevalence of MS in Iran between 8\% and 35\% [7] but, the most of these investigations do not indicate the actual prevalence of MS among the Iranian population. This may be because of applying of different ways containing study design, participants and description of MS in the investigations. Several studies have identified risk factors for MS and cardiovascular disease in general population [8]. However, few studies indicate this issue among rural women. Accordingly, the aim of this study was to identify the prevalence of MS and its risk factors among rural women in the Saeidabad village, East Azarbaijan on province, Iran.

This cross-sectional study was done on the rural women aged 30-49 years in Saeidabad, East Azarbayjan, Iran. The study conducted from January to June 2019 in the primary health center. Participants consisted of 258 women, who were chosen applying Krejcie and Morgan's table. Blood sample for measuring fasting blood glucose, lipid profile was obtained. Simultaneously, the health providers measured their blood pressure in $\mathrm{mm} \mathrm{Hg}$ and waist circumference in $\mathrm{cm}$. The MS was identified based on the National Cholesterol Education Program Adult Treatment Panel III. Data analysis was done applying chi-square test with a $\mathrm{P}<0.05$ by SPSS software (version 16). This study was approved by the Ethics Committee of Tabriz University of Medical Sciences with an ethical approval number of IR.TBZMED.REC.1398.068.

More than half of participants had high waist circumference (51.4\%). The mean age (SD) of women was 45.7(2.2) years. More than $40 \%$ of rural women had MS (41.8\%). Associations among nominal and categorical variables with MS were shown in table1. 


\section{Current Research in Diabetes \& Obesity Journal}

Table 1: Association of variables and metabolic syndrome among 258 rural women, using Chi-square test.

\begin{tabular}{|c|c|c|c|}
\hline Variables & Metabolic Syndrome N (\%) & No Metabolic Syndrome N (\%) & $P$ value \\
\hline \multicolumn{4}{|l|}{ Age group } \\
\hline $30-34$ & $23(21.2)$ & $42(28)$ & \\
\hline $35-39$ & $25(23.1)$ & $36(24)$ & 0.18 \\
\hline $40-44$ & $29(27)$ & $49(32.6)$ & \\
\hline $45-49$ & $31(28.7)$ & $23(15.4)$ & \\
\hline \multicolumn{4}{|c|}{ Marital status } \\
\hline Married & $101(93.5)$ & 147(98) & 0.06 \\
\hline Single & $7(6.5)$ & $3(2)$ & \\
\hline \multicolumn{4}{|l|}{ Smoking } \\
\hline Yes & $5(4.6)$ & $6(4)$ & 0.32 \\
\hline No & $103(95.4)$ & $144(96)$ & \\
\hline \multicolumn{4}{|c|}{ Physical activity } \\
\hline Yes & $25(23.1)$ & $49(32.6)$ & 0.001 \\
\hline No & $83(76.9)$ & $101(67.4)$ & \\
\hline
\end{tabular}

\section{Conclusion}

our study demonstrated that the prevalence of MS was high among rural women and increased with increasing age. The factor of MS that was most prevalent in the rural women included high waist circumference.

\section{Acknowledgements}

We appreciate the all rural women in Saeidabad village participated in this study.

\section{References}

1. Meigs JB (2002) Epidemiology of the metabolic syndrome, 2002. American Journal of Managed Care 8(11Suppl 1): S283-S292.

2. Aguilar M, Bhuket T, Torres S, Liu B, Wong RJ (2015) Prevalence of the metabolic syndrome in the United States, 2003-2012. Jama 313(19): 1973-1974.
3. Gupta R, Deedwania PC, Gupta A, Rastogi S, Panwar RB, et al. (2004) Prevalence of metabolic syndrome in an Indian urban population. Int J Cardiol 97(2): 257-261.

4. Deedwania PC, Gupta R, Sharma KK, Achari V, Gupta B, et al. (2014) High prevalence of metabolic syndrome among urban subjects in India: a multisite study. Diabetes Metab Syndr 8(3): 156-161.

5. Jouyandeh Z, Nayebzadeh F, Qorbani M, Asadi M (2013) Metabolic syndrome and menopause. J Diabetes \& Metab Disord 12(1): 1-4.

6. Lee TY, Yun DS, Lee JG, Park OJ, Park HJ (2006) Prevalence by Factors associated with Metsbolic Syndrome. J Korea Association of Health Promotion 4(1): 85-94.

7. Sayehmiri F (2014) Metabolic syndrome prevalence in Iran: a systematic review and meta-analysis. J Kermanshah Univ Med 18: 242250 .

8. Gheshlagh RG, Parizad N, Sayehmiri K (2016) The relationship between depression and metabolic syndrome: systematic review and meta-analysis study. Iranian Red Crescent Medical Journal 18(6).

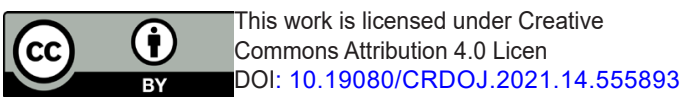

\begin{tabular}{l} 
Your next submission with Juniper Publishers \\
will reach you the below assets \\
- Quality Editorial service \\
- Swift Peer Review \\
- Reprints availability \\
- E-prints Service \\
- Manuscript Podcast for convenient understanding \\
- Global attainment for your research \\
- Manuscript accessibility in different formats \\
( Pdf, E-pub, Full Text, Audio) \\
- Unceasing customer service \\
Track the below URL for one-step submission \\
https://juniperpublishers.com/online-submission.php \\
\hline
\end{tabular}

